\title{
MODIFIKASI MODEL INDEKS JANSEN SEBAGAI ALAT UKUR KINERJA SAHAM SYARIAH
}

\author{
Mohammad Farhan Qudratullah \\ Mathematics Department, Faculty of Science and Technology, UIN Sunan Kalijaga Yogyakarta \\ Email: aching_lo@yahoo.com or mohammad.qudratullah@uin-suka.ac.id
}

\begin{abstract}
The Jansen Index is a measure of stock performance based on the Capital Asset Princing Model (CAPM). The Jansen Index consists of 4 (four) components, namely: stock returns, beta stocks, market returns, and risk-free returns. Many studies approach risk-free returns with interest rates when measuring the performance of Islamic stocks in the Jansen Index model, while interest rates are prohibited in the concept of Islamic finance. This paper discusses the modification of the Jansen Index model to analyze the performance of Islamic stocks with 4 (four) approaches, namely the model without interest rates, models with zakat rates, models with inflation, and models with gross domestic production (GDP) and compare them with models with interest rates (BI-Rate). Then the five models are implemented in the Islamic capital market in Indonesia in the period January 2011 - July 2018.The results obtained are that there is a very high suitability for the measurement results of the five models. Judging from the closeness of the results of performance measurement, the five models can be grouped into 2 (two), namely models with interest rates, inflation, and GDP as the first group, while models without interest rates and zakat-rate as the second group. This means, on the concept of Islamic finance, risk-free returns can be measured using these 4 (four) approaches, specifically inflation or GDP.
\end{abstract}

Keywords: Islamic Finance, Jansen Index, Risk Free Return, and Syariah Stock Performance

\section{PENDAHULUAN}

Seiring makin berkembangnya majunya teknologi informasi dan perdagangan global, investasi saham di pasar modal juga berkembang sangat pesat. Negara yang pertama kali mengimplementasikan prinsip syariah di sektor pasar modal adalah Jordan pada tahun 1978 dan Pakistan pada tahun 1980. Saat ini, reksa dana islami beroperasi terutama di Negara Saudi Arabia, UAE, Bahrain, Kuwait, Qatar, Pakistan, Malaysia, Brunei, Singapura, Jerman, Inggris, Amerika Serikat, Kanada, Swiss, dan Afrika Selatan (Ayub, 2009).

Pasar model syariah di Indonesia berkembang sangat pesat, sejak PT. Bursa Efek Jakarta (BEJ) menerbitkan daftar reksadana, saham, dan obligasi syariah dalam Jakarta Islamic Index (JII) pada 3 Juli 2000, JII terdiri atas 30 saham yang paling liquid di BEI. Pada tanggal 12 Mei 2011, Bursa Efek Indonesia (BEI) meluncurkan Indeks Saham Syariah Indonesia (ISSI), ISSI merupakan indeks saham yang mencerminkan seseluruhan saham sayariah yang tercatat di BEI (Yuniarti dan Litriani, 2017). Selanjutnya pada 17 Mei 2018, BEI meluncurkan Jakarta Islamic Index 70 (JII70) yang terdiri atas atas 70 saham syariah paling liquid yang tercatat di BEI. Dari 2011 - Desember 2018, tercatat bahwa kapitalisasi saham syariah di BEI meningkat lebih dari 90\% dari 1968 Triliun menjadi 3741 Triliun, sementara jumlah emitem saham syariah meningkat 79\% dari 234 emitem manjadi 419 emitem (OJK, 2019). Sedangkan, kapitalisasi saham yang tergabung dalam JII (kapitalisasi 
saham yang tergabung dalam JII mencapai $61 \%$ dari total kapitalisasi saham syariah di BEI) meningkat hampir dari 3000\% dibanding pertama kali diterbitkan tahun 2000 .

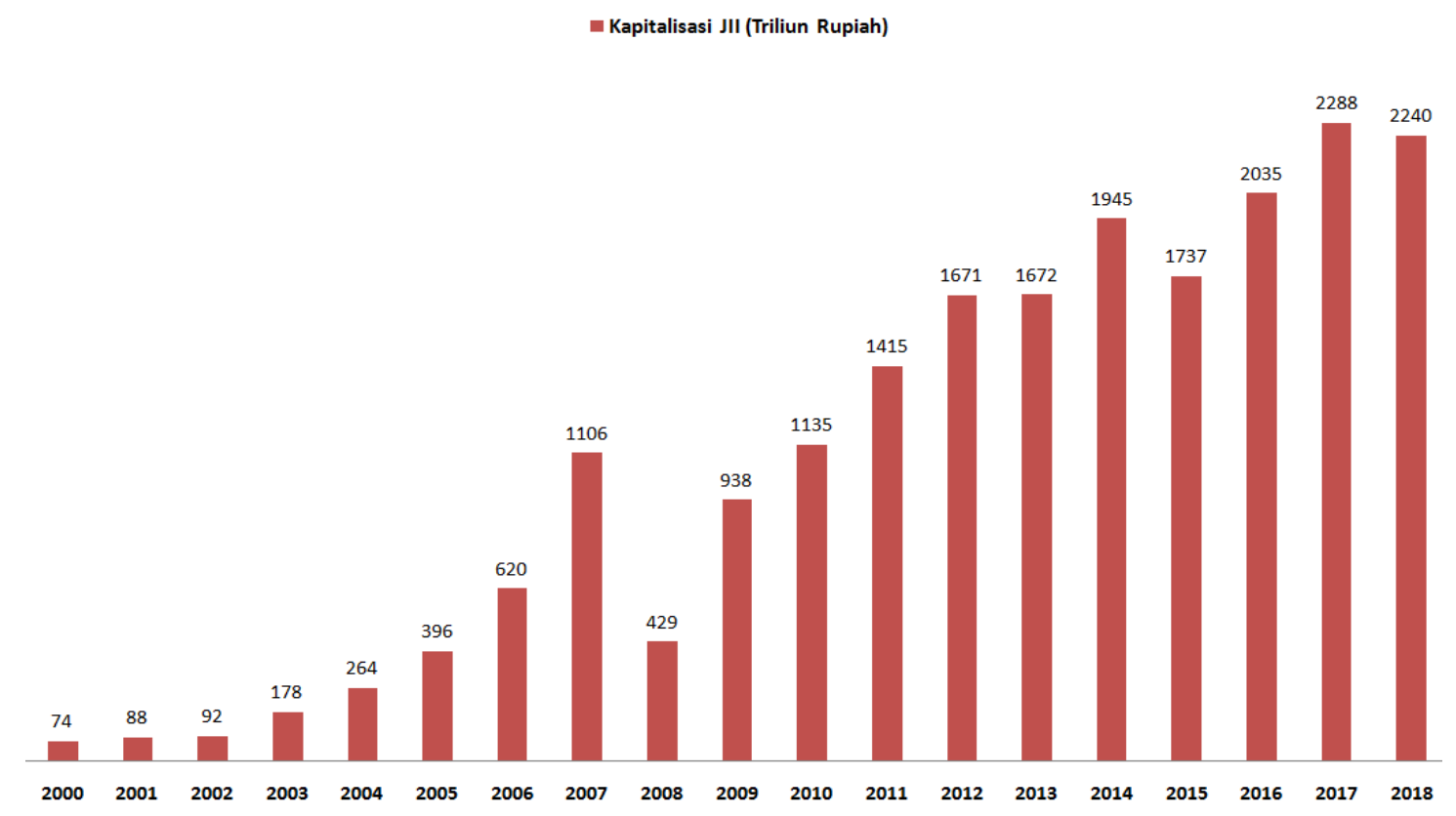

Gambar 1. Kapitalisasi Saham JII Tahun 200-2018

Investasi saham pada pasar modal termasuk pada saham syariah merupakan investasi yang memilki risiko tinggi tetapi memiliki tingkat keuntungan yang tinggi pula (bigh risk-bigh return) (Jogiyanto, 2007). Jika tidak berhati-hati, investasi di bursa saham memungkinkan terjadinya kebangkrutan, sehingga untuk mencegah masalah tersebut perlu adanya manajemen risiko. Salah satu strategi yang direkomendasikan adalah diferensiasi saham dengan membentuk suatu portofolio. Salah satu masalah terbuka dalam membentuk portofolio adalah bagaimana memilih saham-saham pembentuk portofolio dari sekian banyak saham yang ada?. Secara umum, saham yang dipilih adalah saham yang memiliki kinerja terbaik.

Penelitian tentang analisis kinerja saham secara tehnikal mengunakan ukuran kinerja, pertama kali dikemukakan oleh Fried, Brown, Herma, dan Vickers dalam tulisannya 'A Study of Mutual Found' pada tahun 1962 (Redman, Gullet, \& Manakyan, 2000). Beberapa tahun kemudian secara terpisah Treynor (1965), Sharpe (1966), dan Jensen (1967) memperkenalkan model untuk mengukur kinerja saham. Sejak itu, pengembangan model untuk mengukur kinerja saham telah banyak dilakukan dan menghasilkan lebih dari 100 alternatif model khususnya model ukuran kinerja yang disesuaikan dengan risiko (Wiesinger, 2010).

Indeks Jansen adalah salah satu ukuran kinerja saham yang paling populer, sejak diperkenalkan oleh Michael Jansen pada tahun 1967. Indeks Jansen merupakan ukuran kinerja yang disesuaikan dengan risiko relatif (relative risk-adjusted performance measures), sedangkan Sharpe Ratio dan Treynor Ratio merupakan ukuran kinerja yang disesuaikan dengan risiko mutlak (absolute risk-adjusted performance measures) (Sourd, 2007). Indeks Jansen terdiri atas 4 (empat) komponen, yaitu return saham, beta saham, return pasar, dan return bebas risiko. 
Banyak penelitian yang telah mengunakan Indeks Jansen untuk mengukur kinerja saham syariah di Indonesia, biasanya dikombinasikan dengan Treynor Ratio dan Sharpe Ratio, seperti (Utami, et. al., 2011; Hasbullah, et. al., 2013; Setiawan dan Oktariza, 2013; Andhyka, 2017). Terdapat juga penelitian yang membandingkan kinerja saham syariah dan saham konvensional (Hanafi dan Hanafi, 2012; Hamzah dan Yohanes, 2013; Lestari, 2015; Kusumawati, 2016; Huda, et al,. 2017;). Return bebas risiko dalam penelitian-penelitian tersebut masih didekati dengan suku bunga, yaitu Sertifikat Bank Indonesia atau BI Rate.

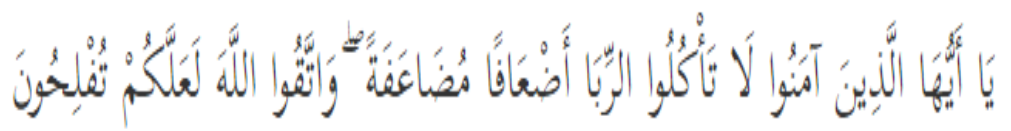

Artinya: 'Hai orang-orang yang beriman, janganlah kamu memakan riba dengan berlipat ganda dan bertakwalah kamu kepada Allah supaya kamu mendapat keberuntungan'

Penggunaan suku bunga tidak sesuai dengan konsep keuangan islam, karena suku bunga digolongkan sebagai riba dan riba dengan tegas dilarang dalam Al-Quran (QS. AlImran (130)). Beberapa peneliti di Indonesia (Kurniawan dan Asandimitra, 2014; Rumintang dan Azhari, 2015; Tulasmi dan Trihariyanto, 2016) mendekati return bebas risiko menggunakan Sertifikat Bank Indonesia Syariah (SBIS) atau Simpanan Wadiah Bank Indonesia Syariah (SWBI) dalam mengukur kinerja saham syariah. Sedangkan beberapa peneliti luar negeri mendekatinya dengan suku bunga di negaranya seperti Kuala Lumpur Inter Bank Offered Rate (KLIBOR) (Mansor dan Bhatti, 2011), Saudi Inter Bank Offered Rate (SIBOR) (Merdad, et. al., 2010; Ashraf, 2013).

Usaha mengganti mencari variabel penganti return bebas risiko pada model Capital Asset Pricing Model (CAPM) yang sesuai dengan syariah telah dilakukan oleh Tomkin dan Karim (1987) dengan menghilangkan variabel suku bunga, el-Askhar (1987) mengganti dengan zakat rate, Sheikh (2010) mengganti dengan nominal gross domestic product growth, dan Hanif (2011) mengantinya dengan inflasi yang selanjutnya dikenal denganmodel Sharia' Complian Asset Pricing Model (SCAPM) atau Islamic Capital Asset Pricing Model (ICAPM).

Untuk itu, tulisan ini mencari variabel alternatif penganti return bebas risiko selain suku bunga pada model Indeks Jansen dengan melakukan 4 (empat) pendekatan, yaitu: menghilangkan variabel suku bunga, mengganti dengan zakat rate, mengganti dengan inflasi, dan mengganti dengan gross domestic produc (GDP) serta melakukan uji empiris pada Bursa Efek Indonesia (BEI), yaitu mengukur kinerja saham-saham syariah yang tergabung dalam Jakarta Islamic Index (JII) periode Januari 2011 - Juli 2018.

\section{LITERATURE REVIEW}

\section{Return Dan Risiko}

Hal mendasar dalam keputusan investasi adalah tingkat keuntungan yang diharapkan (return) dan risiko (risk) (Tandelilin, 2001). Return adalah hasil (tingkat pengembalian) yang diperoleh sebagai akibat dari investasi yang dilakukan. Ada beberapa jenis return yang biasa digunakan dalam perhitungan, yaitu geometrik return atau $\log$ return $\left(\boldsymbol{R}_{\boldsymbol{t}}\right)$.

$$
R_{t}=\ln \left(\frac{P_{t}+D_{t}}{P_{t-1}}\right)
$$


dimana, $P_{t}$ adalah $\log$ return pada periode $t, P_{t-1}$ adalah nilai asset pada periode $t-1$, dan $D_{t}$ adalah deviden pada periode $t$. Jika terdapat $T$ observasi, maka ekspetasi return $\left(E\left(R_{t}\right)=\bar{R}_{t}\right)$ ditulis:

$$
E\left(R_{t}\right)=\frac{\sum_{t=1}^{T} R_{t}}{T}
$$

Risiko didefinisikan sebagai variabilitas return terhadap return yang diharapkan (Van Horne dan Wachowics, Jr., 1992). Untuk menghitung risiko, metode yang banyak digunakan adalah standar deviasi $\left(\sigma_{t}\right)$.

$$
\sigma_{t}=\frac{\sum_{t=1}^{T}\left(R_{t}-\bar{R}_{t}\right)^{2}}{T-1}
$$

Selain standar deviasi, risiko dapat diukur menggunakan beta saham. Beta saham $\left(\beta_{t}\right)$ adalah risiko pengukur risiko sistematik dari suatu saham relatif terhadap risiko pasar $\left(\boldsymbol{R}_{m}\right)$ Jogiyanto, 2007).

$$
\beta_{t}=\frac{\operatorname{Cov}\left(R_{t} ; R_{m}\right)}{\operatorname{Var}\left(R_{m}\right)}
$$

\section{MODEL INDEKS JANSEN DAN MODIFIKASINYA Model Indeks Jansen secara Umum}

Model ini dibuat oleh Jansen pada tahun 1968 yang didasarkan pada Capital Aset Princing Model (CAPM). Pada modelnya Jansen menekankan bahwa hasil Return yang dimaksud adalah Average Return masa lalu, Minimum Rate of Return adalah Expected Return, dan basic risk-adjusted adalah risiko sistematis atau risiko pasar yang diukur dengan beta saham. Berikut rumusan kinerja saham dengan Model Indeks Jansen:

$$
I I=\bar{R}_{t}-\left(\bar{R}_{f}+\beta_{t}\left(E\left(\bar{R}_{m}\right)-\bar{R}_{f}\right)\right)
$$

dimana, $J I$ adalah indeks Jansen saham, $\bar{R}_{t}$ adalah average return saham, $\beta_{t}$ adalah average return saham, $E\left(\bar{R}_{m}\right)$ adalah expected return pasar, dan $\bar{R}_{f}$ adalah return risk free rate

\section{Model Modifikasi Indeks Jansen untuk Saham Syariah}

Model indeks Jansen pada persamaan (5) terdapat masih mengandung unsur return bebas risiko yang biasa diukur dengan suku bunga, sedangkan suku bunga dilarang dalam konsep keuangan islam. Pada model CAPM yang selanjutnya disebut SCAPM atau ICAPM, Tomkin dan Karim (1987) menghilangkan return bebas risiko karena suku bunga dilarang secara syariah, el-Askhar (1987) mengganti dengan zakat rate yang nilainya setara 2,5\%, karena zakat adalah tingkat pengembalian minimum yang diharapkan investor untuk dapat menunaikan kewajiban agama terhadap aset investasi yang dimilki, (2010) mengganti dengan GDP dengan alasan bahwa dibeberapa negara maju GDP membuat suku bunga berubah, sedangkan Hanif (2011) menganti dengan inflasi dengan alasan inflasi terkait 
dengan risiko riil yang harus ditanggung oleh setiap investor dan preferensi pertama seorang investor adalah mempertahankan modalnya kemudian mengharapkan keuntungan.

Dengan mengunakan ide-ide tersebut yang selanjutnya diterapkan pada model Indeks Jansen, diperoleh 4 (empat) model modifikasi dari Indeks Jansen yang tidak bertentangan dengan konsep keuangan islam, yaitu:

- Indeks Jansen tanpa Suku Bunga :

- Indeks Jansen dengan Zakat Rate :

$$
I J-N R F=\bar{R}_{t}-\left(\beta_{t} E\left(\bar{R}_{m}\right)\right)
$$

- Indeks Jansen dengan Inflasi

$$
I J-Z R=\bar{R}_{t}-\left(\bar{Z}+\beta_{t}\left(E\left(\bar{R}_{m}\right)-\bar{Z}\right)\right)
$$

- Indeks Jansen dengan GDP :

$$
I J-I N F=\bar{R}_{t}-\left(\bar{I}+\beta_{t}\left(E\left(\bar{R}_{m}\right)-\bar{I}\right)\right)
$$

$$
I J-G D P=\bar{R}_{t}-\left(\bar{G}+\beta_{t}\left(E\left(\bar{R}_{m}\right)-\bar{G}\right)\right)
$$

dimana: adalah mean BI-Rate, adalah Zakat Rate sebesar 2,5\%/(1-2,5\%) $=2,56 \%$ / tahun, adalah mean Inflasi, dan adalah mean GDP.

\section{METODE ANALISIS DATA}

Data yang digunakan dalam penelitian ini adalah data bulanan periode Januari 2011 - Juli 2018 yang dibagi menjadi 3 (tiga) kelompok, yaitu data pertama periode Januari 2011 Desember 2015 dan data kedua periode Januari 2016 - Juli 2018. Data tersebut terdiri atas data harga penutupan saham syariah yang konsisten tergabung dalam Jakarta Islamic Index (JII) periode Januari 2011 - Desember 2015, data Indeks Harga Saham Gabungan (IHSG), data Sertifikat Bank Indonesi (SBI) atau BI-Rate, Zakat Rate, Inflasi, dan gross domestic produc (GDP).

Berikut langkah-langkah analisis datanya:

1. Hitung return bulanan saham terpilih dan return pasar (IHSG) dengan persamaan (1) untuk setiap kelompok data

2. Hitung nilai return ekspektasi saham dan pasar menggunakan persamaan (2), serta risiko saham yang terdiri atas standar deviasi dan beta saham dengan persamaan (3) dan (4).

3. Hitunglah nilai kinerja saham menggunakan Indeks Jansen yang terdiri atas model dengan suku bunga (BI-Rate) mengunakan persamaan (5), serta 4 (empat) model Modifikasi Indeks Jansen pada persamaan (6), (7), (8), dan (9).

4. Tentukan rank saham masing-masing model berdasarkan hasil pada langkah 3 untuk setiap kelompok data.

5. Lakukan analisis kesesuaian model Indeks Jansen dan modifikasinya menggunakan uji Konkondansi Kendall's untuk keseluruhan model untuk setiap kelompok data yang statistik ujinya (Qudratullah, 2017):

$$
W \quad=\frac{12 \sum_{i=1}^{n} R_{i}^{2}-3 n^{2} m(n+1)}{n^{2} m\left(m^{2}-1\right)}
$$

dimana, $R_{\tilde{i}}$ adalah jumlah Rank saham ke-i, $n$ adalah banyaknya saham, dan $m$ banyaknya model. Lalu, hitung koefisien korelasi Spearman untuk setiap pasang model Indeks Jansen untuk setiap kelompok data (Qudratullah, 2017): 


$$
r_{s}=1-\frac{6 \sum_{i=1}^{k} d_{i}^{2}}{n\left(n^{2}-1\right)}
$$

dimana, $r_{s}$ adalah koefisien korelasi rank Spearman, $d_{i}=\left(R_{A_{i}}-R_{B_{i}}\right), R_{A_{i}}$ adalah rank saham ke- $i$ dari model pertama, dan $R_{B_{i}}$ adalah rank saham ke-i dari model kedua.

6. Buat scaterplot antara rank saham data pertama dan data kedua untuk 5 (lima) model, serta hitung nilai korelasi rank Spearmannya menggunakan persamaan (11) .

7. Lakukan analisis kluster 5 (lima) model modifikasi Indeks Jansen untuk data gabungan. Analisis Kluster adalah analisis untuk mengelompokan elemen yang mirip sebagai objek penelitian menjadi kelompok yang berbeda dan mutually exclusive (Suprapto, 2004). Pengukuran kemiripan dan ketidak miripan antar objek dapat dilakukan dengan ukuran Euclidean yang secara umum dapat ditulis:

$$
d_{A B} \quad=\sqrt{\sum_{i=1}^{n}\left(x_{A i}-x_{B i}\right)^{2}}
$$

dimana, $x_{A i}$ dan $x_{B i}$ adalah nilai kinerja saham ke-i untuk model pertama dan kedua. $d_{A B}$ dapat diartikan jarak antara model pertama dan kedua

\section{HASIL PENELITIAN DAN PEMBAHASAN}

\section{Return dan Risiko Saham}

Terdapat 11 (sebelas) saham yang konsisten masuk JII periode Januari 2011 - Desember 2015. Berikut nilai mean return, standar deviasi, dan beta sahamnya.

Tabel 1

Return dan Risiko Data Pertama

\begin{tabular}{lllccc}
\hline No. & Kode & Nama Saham & Mean & $\begin{array}{c}\text { Std. } \\
\text { Deviasi }\end{array}$ & Beta \\
\hline 1 & AALI & Astra Agro Lestari tbk & $-0,001402$ & 0,097083 & 0,47365 \\
2 & ASII & Astra International tbk & 0,007077 & 0,071616 & 1,20024 \\
3 & ASRI & Alam Sutera Realty tbk & 0,005687 & 0,133452 & 2,03534 \\
4 & INTP & Indocement Tunggal Prakarsa tbk & 0,008735 & 0,085185 & 1,00223 \\
5 & KLBF & Kalbe Farma tbk & 0,015643 & 0,067057 & 0,92298 \\
6 & LPKR & Lippo Karawaci tbk & 0,011386 & 0,111678 & 1,32108 \\
7 & LSIP & PP London Sumatera tbk & $-0,005512$ & 0,136616 & 0,75989 \\
8 & SMGR & Semen Gresik (Persero) tbk & 0,007613 & 0,080079 & 1,38468 \\
9 & TLKM & Telekomunikasi Indonesia tbk & 0,016026 & 0,061762 & 0,56776 \\
10 & UNTR & United Tractors tbk & $-0,000284$ & 0,081653 & 0,89013 \\
11 & UNVR & Unilever Indonesia tbk & 0,016896 & 0,063775 & 0,12674 \\
\hline Sumber: & data diolah & & & &
\end{tabular}


Tabel 2

Return dan Risiko Data Kedua

\begin{tabular}{lllccc}
\hline No. & Kode & Nama Saham & Mean & $\begin{array}{c}\text { Std. } \\
\text { Deviasi }\end{array}$ & Beta \\
\hline 1 & AALI & Astra Agro Lestari tbk & $-0,008435$ & 0,084529 & 0,01302 \\
2 & ASII & Astra International tbk & 0,003288 & 0,056214 & 1,46052 \\
3 & ASRI & Alam Sutera Realty tbk & $-0,001521$ & 0,077147 & 1,21221 \\
4 & INTP & Indocement Tunggal Prakarsa tbk & $-0,008415$ & 0,106237 & 2,18201 \\
5 & KLBF & Kalbe Farma tbk & $-0,003078$ & 0,063825 & 1,47644 \\
6 & LPKR & Lippo Karawaci tbk & $-0,034322$ & 0,089685 & 1,32248 \\
7 & LSIP & PP London Sumatera tbk & $-0,002551$ & 0,100004 & 0,02695 \\
8 & SMGR & Semen Gresik (Persero) tbk & $-0,008139$ & 0,073601 & 1,39115 \\
9 & TLKM & Telekomunikasi Indonesia tbk & 0,000237 & 0,065790 & 0,59147 \\
10 & UNTR & United Tractors tbk & 0,021894 & 0,080760 & 1,39992 \\
11 & UNVR & Unilever Indonesia tbk & 0,004663 & 0,057821 & 1,19492 \\
\hline
\end{tabular}

Sumber: data diolah

Tabel 3. Return dan Risiko Data Gabungan

\begin{tabular}{lllccc}
\hline No. & Kode & Nama Saham & Mean & $\begin{array}{c}\text { Std. } \\
\text { Deviasi }\end{array}$ & Beta \\
\hline 1 & AALI & Astra Agro Lestari tbk & $-0,003798$ & 0,092583 & 0,383431 \\
2 & ASII & Astra International tbk & 0,005786 & 0,066474 & 1,247480 \\
3 & ASRI & Alam Sutera Realty tbk & 0,003232 & 0,116922 & 1,875116 \\
4 & INTP & Indocement Tunggal Prakarsa tbk & 0,002893 & 0,092660 & 1,219563 \\
5 & KLBF & Kalbe Farma tbk & 0,009266 & 0,066221 & 1,020922 \\
6 & LPKR & Lippo Karawaci tbk & $-0,004185$ & 0,106450 & 1,304596 \\
7 & LSIP & PP London Sumatera tbk & $-0,004503$ & 0,124783 & 0,621220 \\
8 & SMGR & Semen Gresik (Persero) tbk & 0,002247 & 0,077884 & 1,379470 \\
9 & TLKM & Telekomunikasi Indonesia tbk & 0,010647 & 0,063246 & 0,566400 \\
10 & UNTR & United Tractors tbk & 0,007271 & 0,081587 & 0,993937 \\
11 & UNVR & Unilever Indonesia tbk & 0,012729 & 0,061764 & 0,325217 \\
\hline Sumber: data diolah & & & &
\end{tabular}

Berdasarkan tabel 1, terdapat 8 (delapan) saham yang memiliki mean return positif dengan saham UNVR yang tertinggi dan terdapat 3 (tiga) saham yang memiliki nilai mean return negatif dengan saham LSIP yang terendah. Sedangkan saham yang memiliki volatilitas terendah adalah TLKM dan saham yang memilki volatilitas tertinggi adalah LSIP. Untuk nilai beta saham, terdapat 5 (lima) saham memilki beta saham di atas 1 (artinya saham ini memilki nilai volatilitas cenderung di atas harga pasar) dengan yang tertinggi adalah ASRI dan terdapat 6 (enam) saham yang memilki beta saham di bawah 1 (artinya sensifitas harga saham ini lebih kecil dari pasar) dengan yang terendah adalah UNVR.

Sementara itu, berdasarkan tabel 2, terdapat 4 (empat) saham yang memiliki mean return positif dengan saham UNTR yang tertinggi dan terdapat 7 (tujuh) saham yang memiliki nilai mean return negatif dengan saham LPKR yang terendah. Sedangkan saham yang memiliki volatilitas terendah adalah ASII dan saham yang memilki volatilitas tertinggi adalah INTP. untuk beta saham, terdapat 8 (delapan) saham yang memilki nilai beta di atas 
1 dengan yang tertingi adalah INTP dan terdapat 3 (tiga) saham yang memilki beta saham di bawah 1 dengan yang terendah adalah AALI.

Berdasarkan data gabungan yang disajikan dalam tabel 3, terdapat 8 (delapan) saham yang memiliki mean return positif dengan saham UNVR yang tertinggi dan terdapat 3 (tiga) saham yang memiliki nilai mean return negatif dengan saham LSIP yang terendah. Sedangkan saham yang memiliki volatilitas terendah adalah UNVR dan saham yang memilki volatilitas tertinggi adalah INTP. Untuk beta saham, gabungan terdapat 6 (enam) saham yang memilki nilai beta diatas 1 dengan yang tertingi adalah ASRI dan terdapat 5 (lima) saham yang memilki beta saham di bawah 1 dengan yang terendah adalah UNVR.

\section{Nilai dan Ranking Saham dengan Model Indeks Jansen}

Pada data pertama, kelima model sama-sama menempatkan saham UNVR, TLKM, KLBF, LPKR, INTP, dan LSIP pada peringkat 1, 2, 3, 4, 5, dan 11. Sedangkan untuk peringkat lainya sedikit berbeda. Misalkan SMGR dan ASII, model IJ, IJ-INF, dan IJ GDP menempatkan SMGR pada peringkat 6 dan ASII pada peringkat 7, sedangkan model IJNRF dan IJ-ZR sebaliknya. Contoh lainnya adalah saham ASRI menempati peringkat 8 untuk 4 (empat) model, yaitu IJ, IJ-ZR, IJ-INF, dan IJ-GDP, sedangkan model IJ-NRF menempatkannya pada peringkat 9. Dari kelima model tersebut 3 (tiga) model menempatkan peringkat yang sama, yaitu IJ, IJ-INF, dan IJ-GDP.

Tabel 4

Nilai dan Peringkat Kinerja Model Modifikasi Indeks Jansen Data Pertama

\begin{tabular}{lcccccccccc}
\hline & \multicolumn{3}{c}{ IJ } & \multicolumn{2}{c}{ IJ - NRF } & \multicolumn{2}{c}{ IJ - Z R } & \multicolumn{2}{c}{ IJ - INF } & \multicolumn{2}{c}{ IJ - GDP } \\
\cline { 2 - 10 } KODE & Nilai & Rank & Nilai & Rank & Nilai & Rank & Nilai & Rank & Nilai & Rank \\
\hline AALI & $-0,00677$ & 10 & $-0,00379$ & 8 & $-0,00492$ & 9 & $-0,00638$ & 10 & $-0,00605$ & 10 \\
ASII & 0,00215 & 7 & 0,00102 & 6 & 0,00145 & 6 & 0,00200 & 7 & 0,00188 & 7 \\
ASRI & 0,00127 & 8 & $-0,00459$ & 9 & $-0,00238$ & 8 & 0,00049 & 8 & $-0,00015$ & 8 \\
INTP & 0,00369 & 5 & 0,00368 & 5 & 0,00368 & 5 & 0,00369 & 5 & 0,00369 & 5 \\
KLBF & 0,01055 & 3 & 0,01098 & 3 & 0,01082 & 3 & 0,01061 & 3 & 0,01065 & 3 \\
LPKR & 0,00653 & 4 & 0,00472 & 4 & 0,00540 & 4 & 0,00629 & 4 & 0,00609 & 4 \\
LSIP & $-0,01071$ & 11 & $-0,00935$ & 11 & $-0,00986$ & 11 & $-0,01053$ & 11 & $-0,01038$ & 11 \\
SMGR & 0,00280 & 6 & 0,00062 & 7 & 0,00145 & 7 & 0,00251 & 6 & 0,00227 & 6 \\
TLKM & 0,01071 & 2 & 0,01316 & 2 & 0,01224 & 2 & 0,01104 & 2 & 0,01131 & 2 \\
UNTR & $-0,00540$ & 9 & $-0,00478$ & 10 & $-0,00501$ & 10 & $-0,00532$ & 9 & $-0,0053$ & 9 \\
UNVR & 0,01131 & 1 & 0,01626 & 1 & 0,01439 & 1 & 0,01197 & 1 & 0,01251 & 1 \\
\hline
\end{tabular}

Sumber: data diolah

Untuk data kedua, kelima model sama-sama menempatkan 4 (empat) saham pada peringkat yang sama, yaitu UNTR, SMGR, INTP, dan LPKR pada peringkat 1, 9, 10, dan 11. Sedangkan peringkat lainnya terdapat cukup berbeda, misalkan saham UNVR menempati ranking 2 untuk model IJ, IJ-ZR, IJ-INF, dan IJ-GDP sedangkan model IJNRF menempatkan pada peringkat 3. Saham TLKM menempati ranking 4 untuk IJ, IJNRF, dan IJ-ZR sedangkan model IJ-INF dan 3. Saham AALI menempati peringkat 8 untuk model IJ, peringkat 6 untuk model IJ-NRF, dan peringkat 7 untuk 3 (tiga) model lainnya. Pada data kedua, terdapat (dua) model yang selalu memberikan hasil yang sama, yaitu IJ-INF dan IJ-GDP. 
Tabel 5

Nilai dan Peringkat Kinerja Model Modifikasi Indeks Jansen Data Kedua

\begin{tabular}{llclccccccc}
\hline & \multicolumn{3}{c}{ IJ } & \multicolumn{2}{c}{ IJ - NRF } & \multicolumn{2}{c}{ IJ - Z R } & \multicolumn{2}{c}{ IJ - INF } & \multicolumn{2}{c}{ IJ - GDP } \\
\cline { 2 - 11 } KODE & Nilai & Rank & Nilai & Rank & Nilai & Rank & Nilai & Rank & Nilai & Rank \\
\hline AALI & $-0,01391$ & 8 & $-0,00853$ & 6 & $-0,01064$ & 7 & $-0,01147$ & 7 & $-0,01135$ & 7 \\
ASII & $-0,00462$ & 3 & $-0,00714$ & 5 & $-0,00615$ & 5 & $-0,00577$ & 5 & $-0,00582$ & 5 \\
ASRI & $-0,00902$ & 6 & $-0,01017$ & 7 & $-0,00972$ & 6 & $-0,00954$ & 6 & $-0,00957$ & 6 \\
INTP & $-0,01754$ & 10 & $-0,02399$ & 10 & $-0,02146$ & 10 & $-0,02047$ & 10 & $-0,02061$ & 10 \\
KLBF & $-0,01102$ & 7 & $-0,01362$ & 8 & $-0,0126$ & 8 & $-0,0122$ & 8 & $-0,01225$ & 8 \\
LPKR & $-0,042$ & 11 & $-0,04376$ & 11 & $-0,04307$ & 11 & $-0,0428$ & 11 & $-0,04284$ & 11 \\
LSIP & $-0,00805$ & 5 & $-0,00274$ & 2 & $-0,00482$ & 3 & $-0,00564$ & 4 & $-0,00553$ & 4 \\
SMGR & $-0,01593$ & 9 & $-0,01807$ & 9 & $-0,01723$ & 9 & $-0,0169$ & 9 & $-0,01695$ & 9 \\
TLKM & $-0,00621$ & 4 & $-0,00399$ & 4 & $-0,00486$ & 4 & $-0,0052$ & 3 & $-0,00515$ & 3 \\
UNTR & 0,014084 & 1 & 0,011902 & 1 & 0,012756 & 1 & 0,013093 & 1 & 0,013046 & 1 \\
UNVR & $-0,0028$ & 2 & $-0,00387$ & 3 & $-0,00345$ & 2 & $-0,00329$ & 2 & $-0,00331$ & 2 \\
\hline
\end{tabular}

Sumber: data diolah

Dan untuk data gabungan, kelima model sama-sama menempatkan 5 (saham) saham pada peringkat yang sama, yaitu UNVR, TLKM, KLBF, dan ASII pada 5 peringkat teratas. Sedangkan lainnya cukup bervariasi. dari kelima model tersebut IJ-INF dan IJ GDP memberikan hasil yang sama.

Tabel 6

Nilai dan Peringkat Kinerja Model Modifikasi Indeks Jansen Data Gabungan

\begin{tabular}{lcccccccccc}
\hline \multirow{2}{*}{ KODE } & \multicolumn{9}{c}{ IJ } & \multicolumn{2}{c}{ IJ - NRF } & \multicolumn{2}{c}{ IJ - Z R } & \multicolumn{2}{c}{ IJ - INF } & \multicolumn{2}{c}{ IJ - GDP } \\
\cline { 2 - 11 } & Nilai & Rank & Nilai & Rank & Nilai & Rank & Nilai & Rank & Nilai & Rank \\
\hline AALI & $-0,00945$ & 9 & $-0,00601$ & 8 & $-0,00732$ & 9 & $-0,00863$ & 9 & $-0,00835$ & 9 \\
ASII & 0,00000 & 5 & $-0,0014$ & 5 & $-0,00087$ & 5 & $-0,00035$ & 5 & $-0,00046$ & 5 \\
ASRI & $-0,00268$ & 6 & $-0,00757$ & 9 & $-0,00570$ & 8 & $-0,00385$ & 7 & $-0,00424$ & 7 \\
INTP & $-0,00291$ & 7 & $-0,00413$ & 6 & $-0,00366$ & 6 & $-0,0032$ & 6 & $-0,00330$ & 6 \\
KLBF & 0,00350 & 3 & 0,00339 & 3 & 0,00343 & 3 & 0,00347 & 3 & 0,00347 & 3 \\
LPKR & $-0,01000$ & 10 & $-0,01170$ & 11 & $-0,01105$ & 11 & $-0,01041$ & 11 & $-0,01054$ & 11 \\
LSIP & $-0,01020$ & 11 & $-0,00808$ & 10 & $-0,00889$ & 10 & $-0,00969$ & 10 & $-0,00952$ & 10 \\
SMGR & $-0,00358$ & 8 & $-0,00570$ & 7 & $-0,00489$ & 7 & $-0,00409$ & 8 & $-0,00426$ & 8 \\
TLKM & 0,00496 & 2 & 0,00739 & 2 & 0,00646 & 2 & 0,00554 & 2 & 0,00574 & 2 \\
UNTR & 0,00151 & 4 & 0,00155 & 4 & 0,00153 & 4 & 0,00152 & 4 & 0,00152 & 4 \\
UNVR & 0,00708 & 1 & 0,01086 & 1 & 0,00941 & 1 & 0,00799 & 1 & 0,00829 & 1 \\
\hline
\end{tabular}

Sumber: data diolah

\section{Analisis Kesesuaian Model Indeks Jansen}

Tabel 7

Hasil Uji Kesesuaian Penilaian Model Indeks Jansen

\begin{tabular}{lcccc}
\hline Kelompok Data & $\begin{array}{c}\text { Kendall's Coef. of } \\
\text { Concordance }\end{array}$ & Chi-Square & Asymp. sig & Keterangan \\
\hline Data Pertama & 0,986 & 49,309 & 0,000 & Sangat sesuai \\
Data Kedua & 0,975 & 48,727 & 0,000 & Sangat sesuai \\
Data Gabungan & 0,983 & 49,127 & 0,000 & Sangat sesuai \\
\hline
\end{tabular}

\section{Tabel 8}


Koefisien Korelasi Antar Model Indeks Jansen

\begin{tabular}{lcccccc}
\hline \multirow{2}{*}{ Pasangan } & \multicolumn{2}{c}{ Data Pertama } & \multicolumn{2}{c}{ Data Kedua } & \multicolumn{2}{c}{ Data Gabungan } \\
\cline { 2 - 7 } & Nilai & Keterangan & Nilai & Keterangan & Nilai & Keterangan \\
\hline IJ - IJ NRF & $0,964^{*}$ & Sangat sesuai & $0,909^{*}$ & Sangat sesuai & $0,936^{*}$ & Sangat sesuai \\
IJ - IJ ZR & $0,982^{*}$ & Sangat sesuai & $0,955^{*}$ & Sangat sesuai & $0,964^{*}$ & Sangat sesuai \\
IJ - IJ INF & $1,000^{*}$ & Sempurna & $0,964^{*}$ & Sangat sesuai & $0,982^{*}$ & Sangat sesuai \\
IJ - MSR GDP & $1,000^{*}$ & Sempurna & $0,964^{*}$ & Sangat sesuai & $0,982^{*}$ & Sangat sesuai \\
IJ NRF - IJ ZR & $0,991^{*}$ & Sangat sesuai & $0,982^{*}$ & Sangat sesuai & $0,991^{*}$ & Sangat sesuai \\
IJ NRF - IJ INF & $0,964^{*}$ & Sangat sesuai & $0,964^{*}$ & Sangat sesuai & $0,973^{*}$ & Sangat sesuai \\
IJ NRF - IJ GDP & $0,964^{*}$ & Sangat sesuai & $0,964^{*}$ & Sangat sesuai & $0,973^{*}$ & Sangat sesuai \\
IJ ZR - IJ INF & $0,982^{*}$ & Sangat sesuai & $0,991^{*}$ & Sangat sesuai & $0,991^{*}$ & Sangat sesuai \\
IJ ZR - IJ GDP & $0,982^{*}$ & Sangat sesuai & $0,991^{*}$ & Sangat sesuai & $0,991^{*}$ & Sangat sesuai \\
IJ INF - IJ GDP & $1,000^{*}$ & Sempurna & $1,000^{*}$ & Sempurna & $1,000^{*}$ & Sempurna \\
\hline *) Signifikan pada tingkat kepercayaan $9 \%^{*}$ & & & & \\
Sumber: data diolah & \multicolumn{7}{c}{} & & & &
\end{tabular}

Analisis kesesuaian hasil pengukuran kelima model modifikasi Indeks Jansen disajikan pada tabel 7, tampak bahwa koefisien kesesuaiannya sangat tinggi, yaitu 0,986 untuk data pertama, 0,975 untuk data kedua, dan 0,983 untuk data gabungan. Untuk melihat lebih detail, pada tabel 8 terlihat kombinasi semua pasangan sangat sesuai dan sempurna. Model yang kombinasinya sempurna untuk semua kelompok data adalah IJ-INF dan IJ-GDP, sedangkan IJ, IJ-GDP, dan IJ-GDP sempurna untuk kelompok data pertama.

\section{Prediksi Model Modifikasi Indeks Jansen}

Untuk melihat kemampuan prediksi masing-masing model modifikasi Indeks Jansen dapat mengunakan scaterplot rank data pertama terhadap rank data kedua yang dilengkapi dengan nilai korelasi Spearmannya.

\section{Gambar 2}

Plot Rank Data Pertama dan Data Kedua pada Model IJ dengan BI-Rate

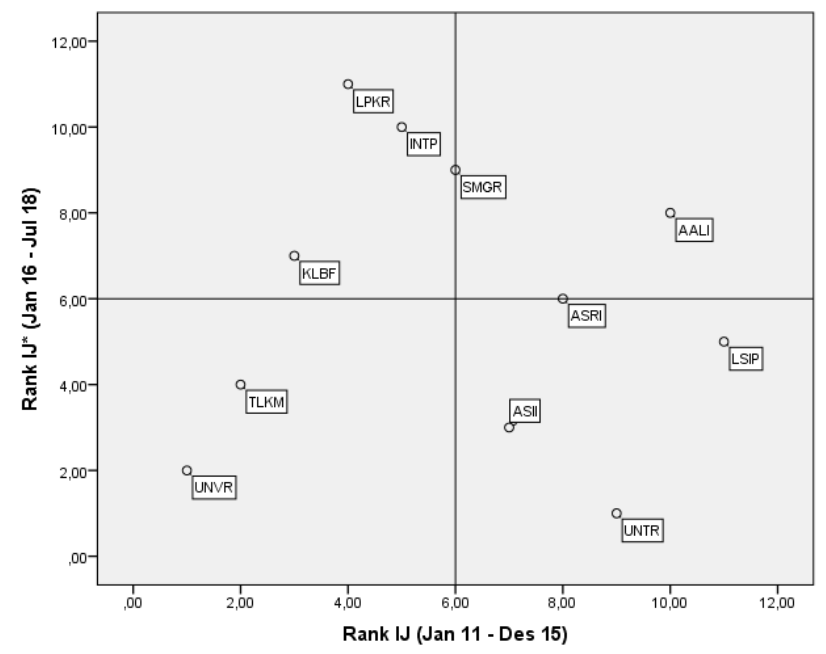

\begin{tabular}{|l|l|}
\hline 3 & 3 \\
\hline 2 & 3 \\
\hline
\end{tabular}

Rank Correlation Coefisient $=-0,036(0,915)$ 


\section{Gambar 3}

Plot Rank Data Pertama dan Data Kedua pada Model IJ Tanpa Suku Bunga

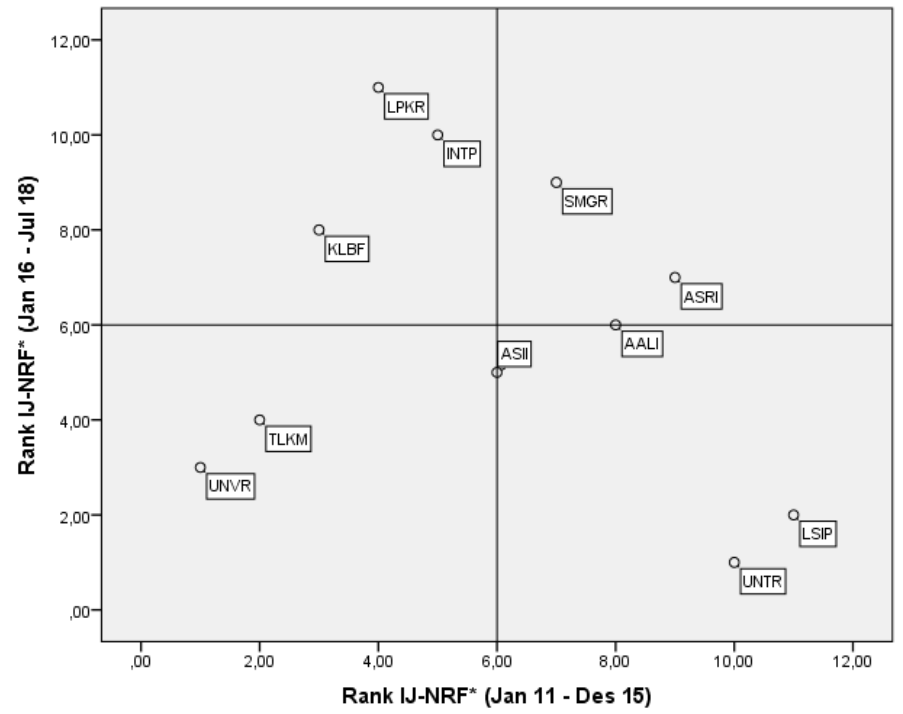

\begin{tabular}{|l|l|}
\hline 3 & 3 \\
\hline 3 & 2 \\
\hline
\end{tabular}

Rank Correlation Coefisient $=-0,282(0,401)$

Gambar 4

Plot Rank Data Pertama dan Data Kedua pada Model IJ dengan Zakat Rate

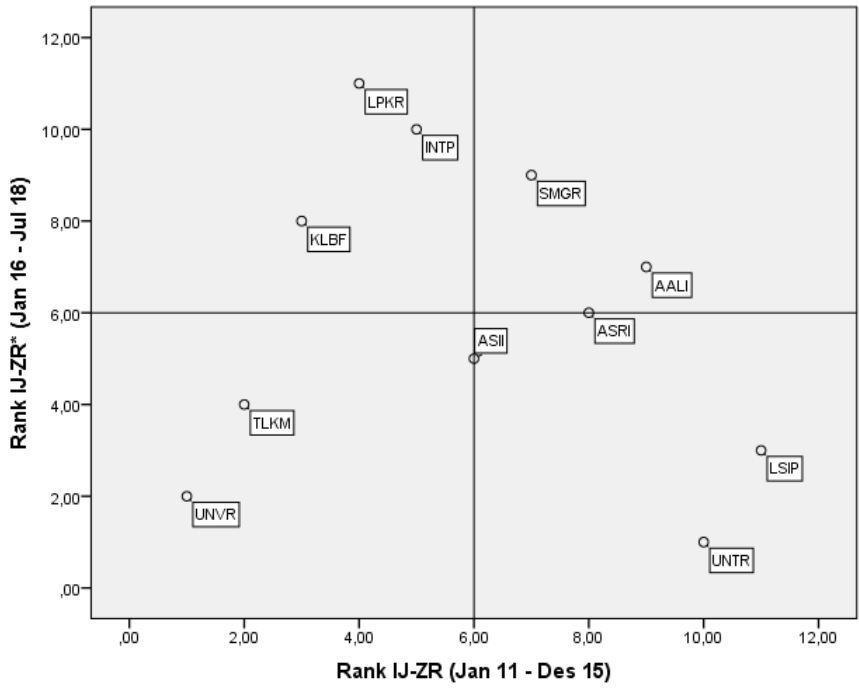

\begin{tabular}{|l|l|}
\hline 3 & 3 \\
\hline 3 & 2 \\
\hline
\end{tabular}

Rank. Correlation Coefisient $=0,191(0,574)$ 
Gambar 5

Plot Rank Data Pertama dan Data Kedua pada Model IJ dengan Inflasi

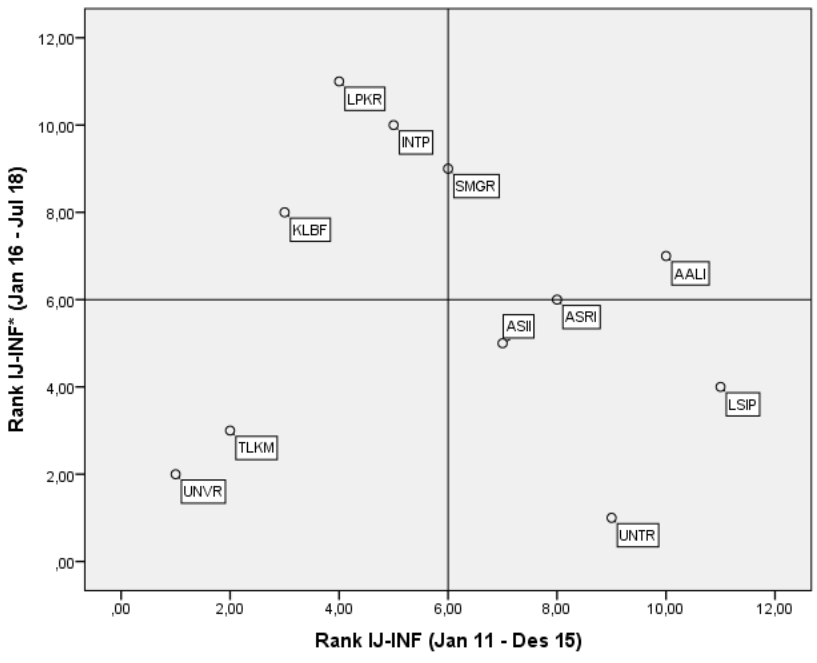

\begin{tabular}{|l|l|}
\hline 3 & 3 \\
\hline 2 & 3 \\
\hline
\end{tabular}

Rank Correlation Coefisient $=-0,091(0,790)$

Gambar 6

Plot Rank Data Pertama dan Data Kedua pada Model IJ dengan GDP

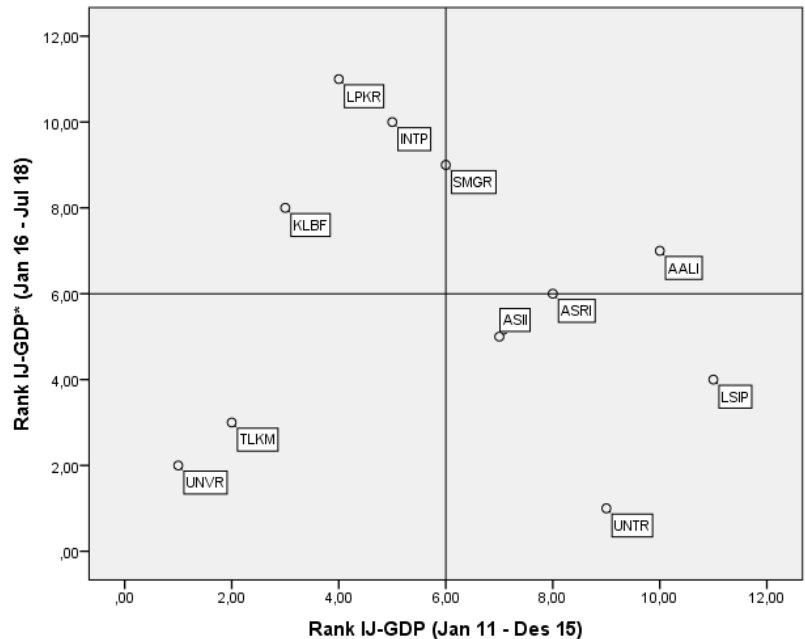

\begin{tabular}{|l|l|}
\hline 3 & 3 \\
\hline 2 & 3 \\
\hline
\end{tabular}

Rank. Correlation Coefisient $=-0,091(0,790)$

Berdasarkan Gambar 2 sampai Gambar 6, tampak bahwa ke-lima model memberikan nilai koefisien yang negatif dengan kategori sangat lemah atau lemah dan tidak signifikan, ini berarti tidak terdapat kesesuaian pengukuran pada data pertama dan kedua, dengan kata lain tidak ada jaminan bahwa saham yang kinerjanya baik pada periode pertama akan baik juga pada periode kedua atau sebaliknya. 


\section{Tabel 8}

Daftar Saham Rekomendasi Model Indeks jansen

\begin{tabular}{ll}
\hline Model & Daftar Saham Kuadran 1 \\
\hline IJ & UNVR; TLKM \\
IJ-NRF & UNVR; TLKM; ASII \\
IJ-ZR & UNVR; TLKM; ASII \\
IJ-INF & UNVR; TLKM \\
IJ-GDP & UNVR; TLKM \\
\hline \multicolumn{2}{c}{ Sumber: data diolah }
\end{tabular}

Tabel 8 disajikan daftar saham yang selalu berada di kuadran pertama atau saham yang cendrerung direkomendasikan untuk masing-masing model Indeks Jansen. Tampak bahwa, model Indeks Jansen dengan BI-Rate, Inflasi, dan GDP merekomendasikan 2 (dua) saham yang sama, yaitu UNVRdan TLKM, sedangkan model Indeks Jansen tanpa suku bunga dan Zakat Rate merekomendasikan 3 (tiga) saham dengan menambahkan saham ASII selain 2 (dua) saham tersebut sebelumnya.

\section{Analisis Kluster Model Indeks Jansen}

Analisis kluster dilakukan untuk mengelompokan kelima model Indeks Jansen kedalam beberapa kelompok yang paling sesuai berdasarkan hasil pengukurannya menggunakan data gabungan.

Gambar 7

Dendogram Analisis Kluster Model IJ

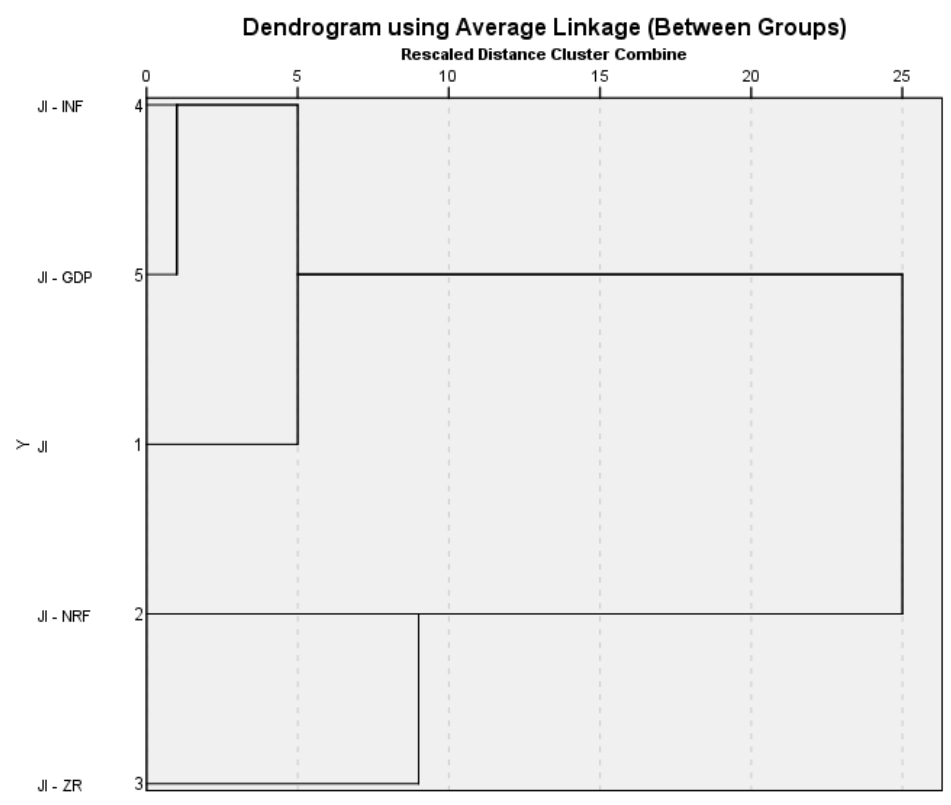


Berdasarkan dendogram pada gambar 7, kelima model modifikasi Indeks Jansen, jika dikelompokan menjadi 2 (dua) kluster diperoleh: kluster pertama terdapat IJ, IJ-INF, dan IJ-GDP, kluster kedua terdapat IJ-NRF dan IJ-ZR.

\section{KESIMPULAN}

Berdasarkan uraian di atas, beberapa kesimpulan yang diperoleh adalah : pertama, kelima model Indeks Jansen baik model yang menggunakan suku bunga, tanpa suku bunga, suku bunga diganti dengan zakat rate, suku bunga diganti dengan inflasi, dan suku bunga diganii dengan GDP memilki nilai kesesuaian model sangat tinggi dalam mengukur kinerja saham syariah. Kedua, kelima model Indeks Jansen tersebut dapat dikelompokan menjadi 2 (dua) kluster berdasarkan hasil pengukurannya: kluster pertama terdiri atas model Indeks jansen dengan suku bunga, model Indeks Jansen dengan Inflasi, dan model Indeks Jansen dengan GDP, kluster kedua terdiri atas model Indeks Jansen tanpa suku bunga dan model Indeks Jansen dengan Zakat Rate. Ketiga, kelima model Indeks Jansen tersebut sama-sama tidak dapat digunakan untuk prediski

\section{REFERENSI}

Andhyka, B., (2017). Sharia Equity Fund Performance Analysis (Indonesia's Case Study). IOSR-JBM: Journal of Bisiness and Management. Volume 19, issue 11. PP 22-23

Ashraf, D., (2013). Performance evaluation of Islamic mutual funds relative to conventional funds: Empirical evidence from Saudi Arabia, International Journal of Islamic and Middle Eastern Finance and Management, Vol. 6 Issue: 2. 105-121,

Ayub, M., (2009). Understanding Islamic Finance: A-Z Keuangan Islam. Jakarta: PT. Gramedia Pustaka Utama. ISBN: 979-979-22-5232-3

Yuniarti, D., dan Litriani, E., (2017). Pengaruh Inflasi dan Nilai Tukar Rupiab terbadap Harga Sabam di Sektor Industri Barang Konsumsi pada Indeks Sabam Syarib di Indonesia (ISSI) Tabun 2012-2016. IFinance Vol. 1. No. 1.31-52

El-Ashker, A. A. F., (1987). The Islamic Business Enterprise. London: Croom Helm. ISBN: 9780709909859

Hamzah, A., dan Yohanes, A., (2014). Analisis Perbandingan Kinerja Reksa Dana Syariah dengan Reksadan Konvensional Jenis Saham pada Periode 2008-012. Jurnal MIX, Volume IV, No. 3, Okt 2014. Hal: 396-409

Hanafi, M.M., dan Hanafi, S.M., (2012). 'Perbandingan Kinerja Investasi Syariab dan Konvensional: Studi pada Jakarta Islamic Indeks (II) dan Indeks LQ45'. Ekbisi: Jurnal Ekonomi dan Bisnis Islam Vol. VII. No.1

Hanif, M., (2011). 'Risk and Return under Shari'a Framework an Attempt to Develop Shari'a Compliant Asset Pricing Model SCAPM'. Pakistan Joural of Commerce and Social Scinces 5:2

Hasbullah, E. S., Mohd, I. B., Mamat, M., Sukono., Rusyaman., E., (2013). Analisis Perbandingan beberapa Sabam Syariah dengan Menggunakan Model Volatilitas Tak Konstan. Statistika Vol 13 No 1. Hal: 25-31

Huda, N., (2017). Analisis Perbandingan Kinerja Reksadana Sabam Syariah dan Konvensional periode 20122015. Iqtishadia: Jurnal Kajian Ekonomi dan Bisnis Islam. Volume 10 No. 2.

Jansen, M.C., (1967). 'The Performance of Mutual Funds In The Period 1945-1964. Journal of Finance, Vol. 23 No.2.

Jogiyanto, H., (2007). Teori Portofollio dan Analisis Investasi, Edisi kelima. Yogyakarta: BPEE. ISBN: 979-503-370-9 
Kurniawan, R. D., dan Asandimitra, N., (2014). Analisis perbandingan Kinerja Sabam Syariah dan Kinerja Saham Konvensional. Jurnal Manajemen, Volume 2 Nomor 4.

Kusumawati, R., (2016). Analisis Reksadana Konvensional dan Reksadana Syariah dengan Menggunakan Metode Sharpe. Jurnal Info Artha. Vol. 4. Page: 151-170

Lestari, W. R., (2015). Kinerja Reksadana Saham Syariab dan Reksadana Sabam Konventional. Jurnal Magister Managemen. Vol. 01. No. 1.

Mansor, F., Bhatti, M.I., (2011). The Islamic Mutual Fund Performance: New Evidence on Market Timing and Stock Selectivity. International Conference on Economics and Finance Research (ICEFR 2011).

Merdad, H., Hassan, M. K., dan Alhenawi, Y., (2010). Islamic Versus Conventional Mutual Funds Performance in Saudi Arabia: A Case Study. JKAU: Islamic Econ., Vol 23. No. 2, pp: 157-193

Otoritas Jasa Keuangan Republik Indonesia. 2018. Statistik Pasar Modal Syariah Indonesia: Januari 2019. http://www.ojk.go.id/ [30 Januari 2019].

Qudratullah, M.F., (2017). "Statistik Nonparametik: Teori Contoh Kasus dan Aplikasi dengan IBM SPSS". Yogyakarta: Penerbit Andi. ISBN: 978-979-29-5304-6

Redman, L. A., Gullet, N. S., \& Manakyan, H. (2000). The performance of global and international mutual funds. Journal of Financial and Strategic Decisions, 13(1), 75-85.

Rumintang, A. G., dan Azhari, M., (2015). Comparative Analysis of Performance of Conventional Equity Fund and Syariah Equyty Fund using Sharpe, Treynor, and Jansen Method in 2014. e-Proceeding of Management: Vol.2, No.2.

Setiawan, C., and Oktariza, H., (2013). Syariah and Conventional Stocks Performance of Public Companies Listed on Indonesia Stock Exchange. Journal of Finance and Economics. Vol. 3. No. 1. Jully 2013. Pp. 51-64

Sharpe, W.F., (1966). 'Mutual Fund Performance'. The Jurnal of Business. Vol. 39. No. 1 Part:2

Sheikh, S.A. (2010). 'Corporate Finance in an Interest Free Economy: An Alternate Approach to Practiced Islamic Corporate Finance'.

Sourd, V. L., (2007). Performance Measurement for Traditional Investment Literature Survey. Edhec Risk And Asset Management Reserch Centre. Lille-Nice: Business School

Suprapto, J. (2004). 'Analisis Multivariat Arti dan Interpretasi'. Jakarta: Rineka Cipta. ISBN: 979$518-902-6$

Tandelilin, E., (2001), Analisis Investasi dan Manajemen Portofolio'. Edisi Pertama, Yogyakarta: BPFEYogyakarta

Tomkins, C., \& Karim, R. A. A. (1987). The Shari'ah and Its Implications for Islamic Financial Analysis: An Opportunity to Study Interactions Among Society, Organization and Accounting. The American Journal of Islamic Social Sciences, 4(1), 101-115.

Treynor, J.L., (1965). 'Haw to Rate Management of Investment Funds'. Harvard Business Review XLIII. pp 63-75

Tulasmi dan Trihariyanto, R. R., (2016). Islamic Stocks Indeks Performance: Comparative Studies Betwen Indonesia and Malaysia. Signifikan: Jurnal Ilmu Ekonomi. Volume 5 (1).

Utami, R. dan Nugraha, M. P. K., (2011). Analisis Kinerja Saham Syariah dan Pengaruhnya terbadap Respon Pasar pada Perusahaan yang Tercatat di Jakarta Islamic Indeks. Jurnal Reviw Akuntansi dan Keuangan. Vo.1 No. 2. 161-172

Van Horne, J. dan Wachowics, Jr., J. M., (1992). Fundamentals of Financial Management. Prentice-Hall International Edition, eigth edition.

Wiesinger, A., (2010). Risk-Adjusted Performance Measurement - State of the Art. Switzerland: University of St. Gallen (HSG), St. Galllen 